\title{
Effects of pretransport diet, transport duration, and type of vehicle on physiological status of young veal calves
}

\author{
F. Marcato, ${ }^{1,2 *} \odot$ H. van den Brand, ${ }^{1} \oplus$ B. Kemp, ${ }^{1}$ B. Engel, ${ }^{3} \oplus$ M. Wolthuis-Fillerup, ${ }^{2} \oplus$ and K. van Reenen ${ }^{2}$ \\ ${ }^{1}$ Adaptation Physiology Group, Department of Animal Sciences, Wageningen University \& Research, PO Box 338, 6700 AH Wageningen, \\ the Netherlands \\ ${ }^{2}$ Livestock Research, Wageningen University \& Research, PO Box 338, $6700 \mathrm{AH}$ Wageningen, the Netherlands \\ ${ }^{3}$ Biometris, Wageningen University \& Research, PO Box 16, 6700 AA Wageningen, the Netherlands
}

\section{ABSTRACT}

This study aimed to investigate effects of pretransport diet (rearing milk vs. electrolytes), type of vehicle (open vs. conditioned truck), and transport duration (6 vs. $18 \mathrm{~h}$ ) on physiological status of young calves upon arrival at the veal farm. A total of 368 calves were transported in 2 consecutive batches from a collection center to a veal farm. Blood samples were collected from calves before transport; immediately posttransport (T0); and 4, 24, and $48 \mathrm{~h}$, and 1, 3, and 5 wk posttransport. Blood was analyzed for glucose, urea, lactate, nonesterified fatty acids (NEFA), $\beta$-hydroxybutyrate (BHB), creatine kinase, albumin, total protein, osmolality, calcium, sodium, magnesium, and hematological variables. Body weight, rectal temperature, and skin elasticity were determined before and immediately posttransport. Blood glucose, NEFA, and urea concentrations at $\mathrm{T} 0$ showed an interaction between pretransport diet and transport duration. Milk-fed and electrolytefed calves transported for $18 \mathrm{~h}$ did not significantly differ in plasma glucose concentration or serum NEFA concentrations. However, after $6 \mathrm{~h}$ of transport, milkfed calves had higher plasma glucose and lower serum NEFA concentrations $(4.71 \mathrm{mmol} / \mathrm{L}$ and $586.5 \mu \mathrm{mol} / \mathrm{L}$, respectively) than electrolyte-fed calves $(3.56 \mathrm{mmol} / \mathrm{L}$ and $916 \mu \mathrm{mol} / \mathrm{L}$, respectively). After $18 \mathrm{~h}$ of transport, milk-fed calves had lower urea concentrations (5.40 $\mathrm{mmol} / \mathrm{L})$ than electrolyte-fed calves $(7.38 \mathrm{mmol} / \mathrm{L})$. In addition, at T0, after $6 \mathrm{~h}$ of transport, milk-fed calves gained weight $(\Delta=0.41 \mathrm{~kg})$, whereas electrolyte-fed calves lost weight $(\Delta=-0.16 \mathrm{~kg})$. After $18 \mathrm{~h}$ of transport, both milk-fed and electrolyte-fed calves showed body weight losses $(\Delta=-0.67$ and $-0.74 \mathrm{~kg}$, respectively). Type of vehicle had a limited influence on blood

Received August 13, 2019.

Accepted December 9, 2019.

*Corresponding author: francesca.marcato@wur.nl parameters. Concentrations of NEFA and BHB reached the maximum values at $\mathrm{T} 0$ and then decreased until wk 5 posttransport. The increase in NEFA and BHB concentrations between prior to and just posttransport (T0) was less pronounced in calves transported for 6 $\mathrm{h}(746.1 \mu \mathrm{mol} / \mathrm{L}$ and $0.38 \mathrm{mmol} / \mathrm{L}$, respectively) than in calves transported for $18 \mathrm{~h}(850.6 \mu \mathrm{mol} / \mathrm{L}$ and 0.50 $\mathrm{mmol} / \mathrm{L}$ ). Overall, the recovery rate of calves at the veal farm seemed rapid; all blood parameters returned to (below) pretransport values within $48 \mathrm{~h}$ posttransport. We concluded that feeding milk before short-term transport helps young veal calves cope with transport, whereas this is not the case during long-term transport. Key words: transport, diet, transport duration, physiology, veal calf

\section{INTRODUCTION}

Veal calves have to deal with several challenges, such as mixing procedures and changes in environment, in their early stages of their life (Hulbert and Moisa, 2016). One of the largest challenges is transport of calves from the dairy farm to a collection center (CC) or auction center, followed by a second transport to the veal farm (Renaud et al., 2018). At the CC, during transport, calves from different farms are mixed together and exposed to new environmental conditions, including new microorganisms, against which they may not have obtained colostral antibodies (Autio et al., 2007). As a result, diseases can spread among veal calves quite easily. Respiratory diseases, and especially bovine respiratory disease, have been shown to have a high (up to 17\%) incidence at the veal farms during the entire fattening period (Pardon et al., 2013; Buczinski et al., 2018).

This high disease prevalence might be related to adverse effects of transport on physiology (Grigor et al., 2001; Minka and Ayo, 2010), immunity (Buckham Sporer et al., 2008; Hulbert and Moisa, 2016), and health (Schwartzkopf-Genswein et al., 2007; Earley et 
al., 2017) of calves. Among cattle, newborn calves are more vulnerable to transport stress than older calves because they have a lower ability to maintain body temperature and osmolality during transport (Schrama et al., 1993; Gebresenbet et al., 2012). Knowles et al. (1997) found relatively greater BW losses and more dehydration in young calves (less than 1 mo old) posttransport compared with older calves (6 mo old). Regarding metabolism, BW losses were more pronounced in calves transported for $24 \mathrm{~h}$ than in calves transported for $8 \mathrm{~h}$ (Knowles et al., 1997). Changes in hematological variables posttransport were noticeable in young calves (Mormede et al., 1982; Knowles et al., 1999). Higher levels of plasma cortisol, nonesterified fatty acids (NEFA), urea, BHB, packed cell volume, neutrophils, basophils, and total white blood cell numbers are commonly found in calves upon arrival at the veal farm (Knowles et al., 1997; Bernardini et al., 2012) compared with pretransport values. These responses are often greater in calves transported for more than 8 h (Knowles et al., 1997; Knowles et al., 1999) compared with calves subjected to short-term transport.

Differences in the hematological profile of calves after transport might be related to different factors, such as age of calves at first transport, handling, pretransport nutrition, transport conditions, type of vehicle, transport duration (Schaefer et al., 1997), and recovery time upon arrival at the veal farm (Pardon et al., 2015; Renaud et al., 2018). Besides transport duration, to our knowledge no studies have been done on the effects of a pretransport diet and type of vehicle on metabolic status of young calves. Knowles et al. (1999) investigated effects of feeding during long-distance transport, but the authors did not include a contrast in diet before transport and they also did not investigate effects on calf metabolic status. Moreover, Bernardini et al. (2012) investigated effects of environmental conditions on health of calves, but not the conditions inside the truck.

The aim of the current study was to investigate effects of a pretransport diet (rearing milk vs. electrolytes), transport duration ( 6 vs. $18 \mathrm{~h}$ ), and transport condition (open truck vs. conditioned truck) on metabolic and physiological variables of young calves upon arrival at the veal farm. Blood parameters were analyzed until wk 5 posttransport to study the recovery time of calves after arrival. We hypothesized that a shorter transport duration has less of an effect on metabolic and physiological parameters of young calves than a longer transport duration; moreover, feeding milk before transport combined with transport in a conditioned truck was assumed to help calves recover faster upon arrival at the veal farm.

\section{MATERIALS AND METHODS}

The current experiment was done under commercial conditions and followed common procedures (calves were transported from different German dairy farms to a German CC and additionally to a Dutch veal farm). All calves were complying with minimal weight and health status requirements ( $\mathrm{BW}>36 \mathrm{~kg}$; age: minimum $14 \mathrm{~d}$; no signs of disease and injury; SBK, 2018). The experimental design was approved by the Central Committee on Animal Experiments (The Hague, the Netherlands; approval number 2017.D-0029). The study was conducted in January 2018 in 2 consecutive batches with a 1-wk interval in between. Calves were transported from a CC, located in Bocholt-Barlo, Germany, to a veal farm in Veghel, the Netherlands.

\section{Experimental Design and Animals}

The experiment was set up as a complete $2 \times 2 \times$ 2 factorial arrangement with 3 factors: (1) provision of rearing milk or electrolytes before transport, (2) transport duration (6 or $18 \mathrm{~h}$ ), and (3) transport condition (open truck or conditioned truck). This resulted in 8 treatments: (1) milk, $6 \mathrm{~h}$ of transport, conditioned truck; (2) milk, $18 \mathrm{~h}$ of transport, conditioned truck; (3) milk, 6 h of transport, open truck; (4) milk, $18 \mathrm{~h}$ of transport, open truck; (5) electrolytes, $6 \mathrm{~h}$ of transport, conditioned truck; (6) electrolytes, $18 \mathrm{~h}$ of transport, conditioned truck; (7) electrolytes, $6 \mathrm{~h}$ of transport, open truck; and (8) electrolytes, $18 \mathrm{~h}$ of transport, open truck.

The study included 368 male Holstein-Friesian and crossbred calves $(18 \pm 4 \mathrm{~d} ; 45.3 \pm 3.3 \mathrm{~kg}$ of $\mathrm{BW} ; \pm$ $\mathrm{SD})$, divided over 2 consecutive batches $(\mathrm{n}=184$ / batch). The sample size was based on the availability of resources and no formal sample size calculation was completed. However, based on previous comparable experiments we expected that the number of replicates was sufficient to obtain reliable results.

\section{Measurements at the CC and Transport of Calves to the Veal Farm}

At the $\mathrm{CC}$, calves were randomly allocated by the manager of the CC to 1 of the 8 treatment groups. Within each batch, 8 calves per treatment group were randomly selected for blood sampling (completed by personnel that were blinded to the treatment groups). After blood sampling, calves were weighed with a digital weighing scale, and rectal temperature $(\mathbf{R T})$ and skin elasticity were determined. Skin elasticity was performed according to Constable et al. (1998) to measure 
Table 1. Mean and range of actual temperature $(\mathrm{T})$ and relative humidity $(\mathrm{RH})$ inside the conditioned and open trucks during short (6 h) or long $(18 \mathrm{~h})$ transportation of young calves to the veal farm

\begin{tabular}{|c|c|c|c|c|c|c|c|c|}
\hline \multirow{2}{*}{ Time } & \multicolumn{4}{|c|}{ Conditioned truck } & \multicolumn{4}{|c|}{ Open truck } \\
\hline & \multicolumn{2}{|c|}{ Batch 1} & \multicolumn{2}{|c|}{ Batch 2} & \multicolumn{2}{|c|}{ Batch 1} & \multicolumn{2}{|c|}{ Batch 2} \\
\hline $6 \mathrm{~h}$ & $\begin{array}{l}9.2 \\
(8.2-10.3)\end{array}$ & $\begin{array}{l}66.0 \\
(61.0-75.1)\end{array}$ & $\begin{array}{l}13.0 \\
(11.7-13.9)\end{array}$ & $\begin{array}{l}74.1 \\
(65.0-81.0)\end{array}$ & $\begin{array}{l}7.4 \\
(6.2-9.1)\end{array}$ & $\begin{array}{l}74.1 \\
(66.3-84.2)\end{array}$ & $\begin{array}{l}11.5 \\
(10.4-12.5)\end{array}$ & $\begin{array}{l}80.3 \\
(67.6-88.8)\end{array}$ \\
\hline $18 \mathrm{~h}$ & $\begin{array}{l}7.8 \\
(4.5-11.2)\end{array}$ & $\begin{array}{l}68.2 \\
(58.5-78.9)\end{array}$ & $\begin{array}{l}13.6 \\
(11.2-16.3)\end{array}$ & $\begin{array}{l}77.9 \\
(65.4-83.9)\end{array}$ & $\begin{array}{l}6.6 \\
(3.9-9.6)\end{array}$ & $\begin{array}{l}75.8 \\
(66.3-86.5)\end{array}$ & $\begin{array}{l}14.0 \\
(10.8-16.6)\end{array}$ & $\begin{array}{l}77.3 \\
(66.2-86.2)\end{array}$ \\
\hline
\end{tabular}

the degree of clinical dehydration of calves and was scored as 0 or 1 with $0=$ normal, skin tent $<1 \mathrm{~s}$, and $1=$ dehydrated, skin tent $>1 \mathrm{~s}$. Thereafter, calves were fed via bucket with nipples, with $1.5 \mathrm{l}$ of rearing milk (125 g of milk powder $/ \mathrm{L} ; \mathrm{ME}=4,028 \mathrm{kcal} / \mathrm{kg}, \mathrm{CP}=$ $190 \mathrm{~g} / \mathrm{kg}$, digestible lysine $=18.7 \mathrm{~g} / \mathrm{kg}$; Tentofok KO, Tentego, the Netherlands) or a mixture of electrolytes (20 g of electrolytes/L of water; Navobi, Staverden, the Netherlands) dissolved in $1.5 \mathrm{~L}$ of water. All calves ingested the respective amount of milk or electrolytes, thus no refusals were observed.

After feeding, calves rested for approximately $2 \mathrm{~h}$ and thereafter they were loaded on the vehicle that was equipped with straw bedding. The vehicle consisted of 2 parts: the truck was conditioned, which means it was provided with a side-ventilation system, it was isolated, and the climate was controlled with regard to inlet and outlet of air (KVM Livestock Transport System, Kleventa BV, Lichtenvoorde, the Netherlands). Settings were according to those provided by the manufacturer and applied by the transporter. The trailer was regular, open, and lacking a ventilation system or climate control. In Table 1, the actual temperatures and relative humidities during transport in the conditioned and open trucks are presented. The settings of the climate control system as applied in practice did not result in notable differences in temperature or relative humidity inside the truck between the conditioned and open vehicles. The actual temperature and relative humidity inside the vehicles were recorded by loggers (n = 8; Escort imini, Cryopak Verification Technologies Inc., Buchanan, VA). Each logger was positioned in the middle of each compartment of truck and trailer, and recorded temperature and humidity every $10 \mathrm{~min}$. Both truck and trailer were divided into 4 compartments with straw bedding: 2 at the lower deck (3.60 $\mathrm{m}$ length $\times 2.45 \mathrm{~m}$ width $\times 1.35 \mathrm{~m}$ height) and 2 at the upper deck $(3.60 \mathrm{~m}$ length $\times 2.45 \mathrm{~m}$ width $\times 1.45$ $\mathrm{m}$ height). Each compartment contained 23 calves and had the same stocking density $\left(0.383 \mathrm{~m}^{2}\right.$ per calf $)$. Each compartment contained calves of 1 of the 8 treatments. Treatments were distributed in the vehicle according to a design that allows for estimation of all main effects and relevant interactions, while avoiding any other confounding (Appendix Figure A1). After loading, transport started with 2 drivers. Drivers switched every $3 \mathrm{~h}$. No food or water were provided to calves during transport. After $6 \mathrm{~h}$ of transport, the truck arrived at the veal farm and all calves were unloaded. Calves assigned to $6 \mathrm{~h}$ of transport were placed in the veal farm, whereas the calves assigned to $18 \mathrm{~h}$ of transport were reloaded on the truck and trailer (in the same compartments as before) and transported for another $12 \mathrm{~h}$. The time invested for the unloading and reloading procedures took approximately $1 \mathrm{~h}$.

\section{Measurements at the Veal Farm}

At the veal farm, a total of 64 pens were available, divided over 8 similar compartments, each containing 8 pens, with 5 or 6 calves per pen. Within each compartment, all treatments were randomly distributed across pens. For the first 3 wk after arrival at the veal farm, calves were individually housed within each pen. After $3 \mathrm{wk}$, the temporary partitions were removed and calves were effectively kept in groups thereafter. Upon arrival at the veal farm, calves $(\mathrm{n}=368)$ were weighed and placed in pens. Immediately after placement (T0) and $4 \mathrm{~h}$ (T4) later, 2 calves per pen were selected for blood sampling (same calves as at the CC) and the individual calf was considered as the experimental unit. In between these 2 blood sampling moments, RT and skin elasticity were measured for all animals. All calves received electrolytes (20 g of electrolytes/L of water; Navobi, Staverden, the Netherlands) dissolved in 3 L of water after blood sampling. Calves selected for blood collection, transported for either 6 or $18 \mathrm{~h}$, were subjected to blood sampling again $24 \mathrm{~h}$ (T24) and 48 $\mathrm{h}$ (T48) after arrival at the veal farm. Furthermore, blood samples of these calves were collected after 1, 3, and 5 wk after arrival at the veal farm.

In the current experiment, the times of feeding at the collection and of departure of the vehicle from the CC $(1400 \mathrm{~h})$ were the same for all calves. This means that 
calves in the 6 -h group arrived in the evening (2000 h) at the veal farm, whereas calves in the 18-h group arrived in the morning ( $0800 \mathrm{~h}$ of the next day). Despite the difference in the actual clock time, for both groups of calves, provision of electrolytes dissolved in water always took place directly posttransport and the first milk replacer meal was given $9 \mathrm{~h}$ posttransport. Therefore, intervals between feeding times and blood sampling times were the same for both transport durations. At the veal farm, calves were also fed milk replacer $(125$ $\mathrm{g}$ of milk powder $/ \mathrm{L} ; \mathrm{ME}=4,028 \mathrm{kcal} / \mathrm{kg}, \mathrm{CP}=210 \mathrm{~g} /$ $\mathrm{kg}$, lysine $=26.0 \mathrm{~g} / \mathrm{kg}$; Navobi).

\section{Blood Sampling and Analyses}

Blood samples were taken via jugular venipuncture at the CC before transport, T0, T4, T24, T48, and wk 1,3 , and 5 after arrival at the veal farm. Blood was collected in different vacutainer tubes (Vacuette, Greiner BioOne, Kremsmunster, Austria), including heparin and EDTA for plasma and serum. All samples were stored at $4^{\circ} \mathrm{C}$ before the analyses, with the exception of serum samples that were stored at room temperature. Part of the samples was then analyzed by fluorescence flow cytometry (XT1800VET, Sysmex Europe GmbH, Norderstedt, Germany) for hemoglobin (Hb), hematocrit (Ht), red blood cells (RBC), mean corpuscular hemoglobin (MCH), mean corpuscular volume (MCV), mean corpuscular hemoglobin concentration (MCHC), and red cell distribution width (RDW). These analyses were only done on samples collected at the CC and at T0. The other blood samples were centrifuged $(3,000$ $\times g$ for $10 \mathrm{~min}, 4^{\circ} \mathrm{C}$ ) and plasma or serum was decanted and stored at $-20^{\circ} \mathrm{C}$. Plasma samples were analyzed for glucose, lactate, urea, albumin, total protein (TP), calcium, and magnesium. Serum samples were analyzed for NEFA, BHB, creatine kinase (CK), and sodium. Glucose was analyzed with a commercially available kit (Roche Diagnostics Nederland B.V., Almere, the Netherlands). Mass spectrophotometry based on commercially available kits was used for analyzing lactate (Diagnostic Systems GmbH, Holzheim, Germany), urea, albumin, TP, calcium, magnesium, sodium (Human, Wiesbaden, Germany), and NEFA (Wako Chemicals GmbH, Neuss, Germany). Osmolality was calculated as osmolality $(\mathrm{mosmol} / \mathrm{kg})=2 \times \operatorname{sodium}(\mathrm{mmol} / \mathrm{L})+$ urea $(\mathrm{mmol} / \mathrm{L})+$ glucose $(\mathrm{mmol} / \mathrm{L})$.

\section{Statistical Analyses}

All statistical analyses were performed with SAS 9.4 (SAS Institute Inc., Cary, NC). First, the analyses of data on immediate posttransport (T0), including hematological data (Hb, Ht, RBC, MCH, MCV, and $\mathrm{MCHC}$ ), physiological data (TP, albumin, osmolality, glucose, urea, lactate, NEFA, and minerals), BW, and RT were analyzed. Continuous data, such as BW, were analyzed with a linear mixed model (analysis with restricted maximum likelihood with SAS procedure PROC MIXED). Residuals were checked for normality and homogeneity of variance and variables were log-transformed when needed. Data expressed as proportions, such as Ht, were analyzed with a generalized linear mixed model (analysis with penalized quasi-likelihood with SAS procedure GLIMMIX), with a logit link function, specifying the "error" variance as a multiple of the binomial variance. Both the linear mixed model and the generalized linear mixed model comprised the following fixed effects in the systematic part of the model (the linear predictor part):

$$
\begin{gathered}
\mu+\text { Batch }_{\mathrm{i}}+\text { Uplo }_{\mathrm{j}}+\text { Bafr }_{\mathrm{k}}+\text { Diet }_{\mathrm{l}}+\text { Type }_{\mathrm{m}} \\
+ \text { Duration }_{\mathrm{n}}+\left(\text { Diet }_{\mathrm{l}} \times \text { Duration }_{\mathrm{n}}\right) \\
+\left(\text { Diet }_{\mathrm{l}} \times \text { Type }_{\mathrm{m}}\right)+\left(\text { Duration }_{\mathrm{n}} \times \text { Type }_{\mathrm{m}}\right) \\
+\left(\text { Diet }_{\mathrm{l}} \times \text { Type }_{\mathrm{m}} \times \text { Duration }_{\mathrm{n}}\right)
\end{gathered}
$$

where $\mu$ is the base level, and Batch (i=1,2), Uplo $_{\mathrm{j}}=$ position in the vehicle $(\mathrm{j}=$ upper or lower deck $), \operatorname{Bafr}_{\mathrm{k}}$ $=$ position in the vehicle $(\mathrm{k}=$ front or back $)$, Diet $_{1}=$ diet before transport $(1=$ rearing milk or electrolytes), Type $_{\mathrm{m}}=$ type of vehicle $(\mathrm{m}=$ open or conditioned truck), and Duration $_{\mathrm{n}}=$ transport duration $(\mathrm{n}=6$ or $18 \mathrm{~h}$ ). The model also comprised 2- and 3-way interactions between diet, type of vehicle, and transport duration. Interactions were considered not significant when $P>0.05$. In addition, random effects for pen and compartment at the veal farm were included (in the linear predictor). Here, and in the subsequent analyses, for all fixed effects, approximate $F$-tests were used (Kenward and Roger, 1997). Interactions that were not significant were excluded from the model (when higher order interactions were already excluded, i.e., respecting the hierarchy of interaction terms) and subsequent pairwise comparisons were done with Fisher's least significant difference method.

Second, physiological data (TP, albumin, osmolality, glucose, urea, lactate, NEFA, CK, BHB, and minerals) and hematological data ( $\mathrm{Ht}$ and $\mathrm{Hb}$ ) from $\mathrm{T0}$ until wk 3 were analyzed with a linear mixed model for continuous data or with a generalized linear mixed model for proportional data. The systematic part of these models comprised the following fixed effects: 


$$
\begin{gathered}
\mu+\text { Batch }_{\mathrm{i}}+\text { Uplo }_{\mathrm{j}}+\text { Bafr }_{\mathrm{k}}+\text { Diet }_{\mathrm{l}}+\text { Type }_{\mathrm{m}} \\
+ \text { Duration }_{\mathrm{n}}+\text { Time }_{\mathrm{o}}+\left(\text { Diet }_{\mathrm{l}} \times \text { Duration }_{\mathrm{n}}\right) \\
+\left(\text { Diet }_{\mathrm{l}} \times \text { Type }_{\mathrm{m}}\right)+\left(\text { Duration }_{\mathrm{n}} \times \text { Type }_{\mathrm{m}}\right) \\
+\left(\text { Diet }_{\mathrm{l}} \times \text { Time }_{\mathrm{o}}\right)+\left(\text { Duration }_{\mathrm{n}} \times \text { Time }_{\mathrm{o}}\right) \\
+\left(\text { Type }_{\mathrm{m}} \times \text { Time }_{\mathrm{o}}\right)+\left(\text { Diet }_{\mathrm{l}} \times \text { Type }_{\mathrm{m}} \times \text { Duration }_{\mathrm{n}}\right)
\end{gathered}
$$

where $\mu$ is the base level, and Batch ( $\mathrm{i}=1,2), \mathrm{Uplo}_{\mathrm{j}}=$ position in the vehicle $\left(\mathrm{j}=\right.$ upper or lower deck), $\mathrm{Bafr}_{\mathrm{k}}$ $=$ position in the vehicle $(\mathrm{k}=$ front or back $)$, Diet ${ }_{1}=$ diet before transport $(\mathrm{l}=$ rearing milk or electrolytes $)$, Type $_{\mathrm{m}}=$ type of vehicle $(\mathrm{m}=$ open or conditioned truck), Duration $\mathrm{n}=$ transport duration $(\mathrm{n}=6$ or 18 $\mathrm{h})$, and $\mathrm{Time}_{\mathrm{o}}=$ sampling moment $(\mathrm{o}=\mathrm{CC}, \mathrm{T} 0, \mathrm{~T} 4$, T24, T48, wk 1, wk 3). Three-way interactions between diet, type of vehicle, transport duration, and 2-way interactions between diet, type of vehicle, transport duration, and time were also included in the model. Interactions were considered not significant when $P>$ 0.05. The model comprised random pen, compartment, and animal effects. For the animal effects, a first-order autoregressive model (based on the actual distance between time points) was adopted to introduce correlation in the model between repeated measurements on the same animal.

Third, physiological data and hematological data (Ht and $\mathrm{Hb}$ ) of wk 5 were analyzed similar to the analysis of data immediate posttransport with a linear mixed model. Although calves were housed individually in baby boxes until wk 3, they were in group pens from wk 5 onward, so random pen effects were included in the model.

Finally, differences between pre- and posttransport measurements (deltas, $\Delta=\mathrm{T} 0-\mathrm{CC}$ ) were calculated for hematological data $(\mathrm{Hb}, \mathrm{Ht}, \mathrm{RBC}, \mathrm{MCH}, \mathrm{MCV}$, and $\mathrm{MCHC}$ ), physiological data (TP, albumin, osmolality, glucose, urea, lactate, NEFA, CK, BHB, and minerals), BW, and RT. These differences were also analyzed similar to the data immediately posttransport with a linear mixed model.

A statistical test was performed to determine whether values at the $\mathrm{CC}$ were comparable between treatment groups. The statistical model was similar to the one used to describe effects at T0, but without interactions. No statistical differences were found between treatment groups.

\section{RESULTS}

The average values of BW, RT, and all blood parameters measured at the CC are shown in Table 2. Moreover, the skin elasticity test results showed that $70 \%$ of calves at the $\mathrm{CC}$ were scored as dehydrated. The 3 -way interactions and 2-way interaction between transport duration and type of vehicle were not significant in this study. Therefore, results will be shown in 4 main parts: (1) 2-way interaction between pretransport diet and transport duration (Table 3); (2) 2-way interaction between pretransport diet and type of vehicle (Table 4); (3) main effects of pretransport diet, type of vehicle, and transport duration, only if interactions are not significant (Table 5); and (4) effects of treatment in time until 5 wk posttransport (Figures 1 and 2). Within the first 3 parts, results will be presented at 2 levels: (1) effects of treatments immediately posttransport (T0: Tables 3 and 5), and (2) effects of treatments on the difference between pre- and posttransport measurements (deltas, $\Delta=$ T0 - CC; Tables 3, 4, and 6).

\section{Interaction Between Pretransport Diet and Transport Duration}

Effects on Measurements Immediately Posttransport. An interaction between pretransport diet and transport duration was detected for glucose, urea, and NEFA (Table 3). Calves fed milk or electrolytes and transported for $18 \mathrm{~h}$ did not differ in blood glucose or NEFA concentrations. However, after $6 \mathrm{~h}$ of transport, milk-fed calves had higher glucose concentrations than electrolyte-fed calves $(\Delta=1.15 \mathrm{mmol} / \mathrm{L} ; P<0.0001)$ and lower NEFA concentrations $(\Delta=-329.5 \mu \mathrm{mol} / \mathrm{L}$; $P=0.007)$. In addition, milk-fed calves transported for $6 \mathrm{~h}$ had higher glucose and lower NEFA concentrations than milk-fed calves transported for $18 \mathrm{~h}(\Delta$ $=1.61 \mathrm{mmo} / \mathrm{L} ; \Delta=-266.7 \mu \mathrm{mol} / \mathrm{L}$, respectively). Blood urea concentration did not differ in milk-fed or electrolyte-fed calves transported for $6 \mathrm{~h}$, but after $18 \mathrm{~h}$ of transport, milk-fed calves had lower urea concentrations than electrolyte-fed calves $(\Delta=-1.98 \mathrm{mmol} / \mathrm{L}$; $P=0.04)$. Moreover, electrolyte-fed calves transported for $6 \mathrm{~h}$ had lower urea concentrations than the ones transported for $18 \mathrm{~h}(\Delta=-1.74 \mathrm{mmol} / \mathrm{L})$.

An interaction between pretransport diet and transport duration was also found for TP, osmolality, and calcium. Higher plasma TP concentrations were found in milk-fed calves than in electrolyte-fed calves after $6 \mathrm{~h}$ of transport $(\Delta=7.09 \mathrm{~g} / \mathrm{L})$, whereas after $18 \mathrm{~h}$ of transport, TP concentrations were lower in milk-fed calves than in electrolyte-fed calves $(\Delta=-5.15 \mathrm{~g} / \mathrm{L} ; P$ $=0.001)$. In addition, milk-fed calves transported for $6 \mathrm{~h}$ had higher TP concentrations than the ones transported for $18 \mathrm{~h}(\Delta=7.28 \mathrm{~g} / \mathrm{L})$, whereas electrolyte-fed calves transported for $6 \mathrm{~h}$ had lower TP concentrations than the ones transported for $18 \mathrm{~h}(\Delta=-4.96 \mathrm{~g} / \mathrm{L})$. Milk-fed and electrolyte-fed calves transported for $6 \mathrm{~h}$ did not differ in osmolality and calcium concentrations. However, after $18 \mathrm{~h}$ of transport, milk-fed calves had a 
Table 2. Mean and range of BW, rectal temperature, and blood parameters measured at the collection center (CC) and comparison of these values with the reference values of calves of $14 \mathrm{~d}$ of age in other studies

\begin{tabular}{|c|c|c|c|c|}
\hline Parameter & Mean and range at the $\mathrm{CC}$ & $\mathrm{SEM}^{1}$ & Knowles et al., 2000 & Mohri et al., 2007 \\
\hline Rectal temperature, ${ }^{\circ} \mathrm{C}$ & $38.6(36.0-40.1)$ & 0.03 & & \\
\hline Hematocrit, \% & $28.8(18.5-40.8)$ & 0.5 & 37.0 & \\
\hline Red blood cells, $10^{12} / \mathrm{L}$ & $8.1(5.3-10.7)$ & 0.1 & 9.5 & 7.5 \\
\hline $\mathrm{MCH}^{2}{ }^{2}$ amol & $735.7(554.0-901.5)$ & 5.4 & 776.0 & \\
\hline $\mathrm{MCV}^{3}, \mathrm{fL}$ & $35.5(29.0-44.3)$ & 0.3 & 40.0 & 34.0 \\
\hline Lactate, $\mathrm{mmol} / \mathrm{L}$ & $1.3(0.6-4.3)$ & 0.05 & & \\
\hline $\mathrm{BHB}, \mathrm{mmol} / \mathrm{L}$ & $0.29(0.06-0.73)$ & 0.01 & 0.12 & \\
\hline Creatine kinase, U/L & $87.1(16.0-375.0)$ & 4.0 & 100.0 & \\
\hline Glucose, $\mathrm{mmol} / \mathrm{L}$ & $3.7(2.3-6.3)$ & 0.1 & 6.0 & 4.3 \\
\hline Urea, $\mathrm{mmol} / \mathrm{L}$ & $5.1(2.1-18.4)$ & 0.2 & 2.7 & 4.7 \\
\hline $\mathrm{NEFA},{ }^{5} \mu \mathrm{mol} / \mathrm{L}$ & $676.0(162.5-1,875.0)$ & 21.4 & 250.0 & \\
\hline Total protein, $\mathrm{g} / \mathrm{L}$ & $64.0(45.1-92.4)$ & 0.6 & 58.0 & 60.0 \\
\hline
\end{tabular}

${ }^{1} \mathrm{SEM}=$ pooled standard error.

${ }^{2} \mathrm{MCH}=$ mean corpuscular hemoglobin.

${ }^{3} \mathrm{MCV}=$ mean corpuscular volume.

${ }^{4} \mathrm{MCHC}=$ mean corpuscular hemoglobin concentration.

${ }^{5} \mathrm{NEFA}=$ nonesterified fatty acids.

lower osmolality and calcium concentrations than electrolyte-fed calves $(\Delta=-14.5 \mathrm{mosmol} / \mathrm{kg}, P=0.02 ; \Delta$ $=-0.15 \mathrm{mmol} / \mathrm{L}, P=0.02$, respectively). Moreover, milk-fed calves transported for $6 \mathrm{~h}$ had higher calcium concentrations than the ones transported for $18 \mathrm{~h}(\Delta$ $=0.29 \mathrm{mmol} / \mathrm{L})$.

Effects on the Difference Between Pre- and Posttransport Measurements. An interaction between pretransport diet and transport duration was identified for glucose, NEFA, and TP (Table 3). Milk-fed and electrolyte-fed calves transported for $18 \mathrm{~h}$ decreased to the same degree in glucose concentration during transport. However, calves transported for $6 \mathrm{~h}$ differed in their responses; milk-fed calves increased in blood glucose concentration, whereas electrolyte-fed calves decreased in glucose concentration $(P=0.0001)$.

Table 3. Interaction between pretransport diet (milk vs. electrolytes) and transport duration (6 vs. 18 h) detected in blood parameters measured immediately posttransport and on the difference between pretransport (collection center, CC) and posttransport $(0 \mathrm{~h}, \mathrm{~T} 0)$ measurements (deltas, $\Delta=\mathrm{T} 0-\mathrm{CC}$ ) in young veal calves (LSM)

\begin{tabular}{|c|c|c|c|c|c|c|}
\hline \multirow[b]{2}{*}{ Parameter } & \multicolumn{2}{|c|}{ Milk } & \multicolumn{2}{|c|}{ Electrolytes } & \multirow[b]{2}{*}{$\operatorname{SEM}^{1}$} & \multirow{2}{*}{$\begin{array}{c}P \text {-value } \\
\text { interaction }\end{array}$} \\
\hline & $6 \mathrm{~h}$ & $18 \mathrm{~h}$ & $6 \mathrm{~h}$ & $18 \mathrm{~h}$ & & \\
\hline \multicolumn{7}{|l|}{ Immediatly posttransport } \\
\hline Glucose, $\mathrm{mmol} / \mathrm{L}$ & $4.71^{\mathrm{a}}$ & $3.10^{\mathrm{b}}$ & $3.56^{\mathrm{b}}$ & $3.35^{\mathrm{b}}$ & 0.14 & $<0.01$ \\
\hline Urea, $\mathrm{mmol} / \mathrm{L}$ & $5.51^{\mathrm{b}}$ & $5.40^{\mathrm{b}}$ & $5.64^{\mathrm{b}}$ & $7.38^{\mathrm{a}}$ & 0.42 & 0.04 \\
\hline $\mathrm{NEFA}^{2}, \mu \mathrm{mol} / \mathrm{L}$ & $586.5^{\mathrm{b}}$ & $853.2^{\mathrm{a}}$ & $916.0^{\mathrm{a}}$ & $837.7^{\mathrm{a}}$ & 54.8 & $<0.01$ \\
\hline Total protein, g/L & $66.90^{\mathrm{a}}$ & $59.62^{\mathrm{b}}$ & $59.81^{\mathrm{b}}$ & $64.77^{\mathrm{a}}$ & 1.65 & $<0.01$ \\
\hline Osmolality, mosmol/kg & $310.6^{\mathrm{ab}}$ & $297.5^{\mathrm{b}}$ & $300.6^{\mathrm{ab}}$ & $312.0^{\mathrm{a}}$ & 4.5 & 0.02 \\
\hline Calcium, $\mathrm{mmol} / \mathrm{L}$ & $2.56^{\mathrm{a}}$ & $2.27^{\mathrm{b}}$ & $2.45^{\mathrm{a}}$ & $2.42^{\mathrm{a}}$ & 2.43 & 0.02 \\
\hline \multicolumn{7}{|l|}{$\Delta=\mathrm{T} 0-\mathrm{CC}$} \\
\hline Glucose, $\mathrm{mmol} / \mathrm{L}$ & $1.19^{\mathrm{a}}$ & $-0.60^{\mathrm{b}}$ & $-0.21^{\mathrm{b}}$ & $-0.62^{\mathrm{b}}$ & 0.15 & $<0.01$ \\
\hline $\mathrm{NEFA}, \mu \mathrm{mol} / \mathrm{L}^{\prime}$ & $-114.6^{\mathrm{b}}$ & $199.3^{\mathrm{a}}$ & $251.1^{\mathrm{a}}$ & $153.7^{\mathrm{a}}$ & 63.0 & $<0.01$ \\
\hline Total protein, $\mathrm{g} / \mathrm{L}$ & $3.60^{\mathrm{b}}$ & $-4.34^{\mathrm{a}}$ & $-2.92^{\mathrm{a}}$ & $-0.65^{\mathrm{a}}$ & 1.56 & $<0.01$ \\
\hline BW losses, kg & $0.41^{\mathrm{a}}$ & $-0.67^{\mathrm{c}}$ & $-0.16^{\mathrm{b}}$ & $-0.74^{\mathrm{c}}$ & 0.09 & 0.03 \\
\hline
\end{tabular}

${ }^{a-c}$ Least squares means within a row lacking a common superscript differ $(P \leq 0.05)$.

${ }^{1} \mathrm{SEM}=$ pooled standard error.

${ }^{2} \mathrm{NEFA}=$ nonesterified fatty acids. 
Table 4. Interaction between pretransport diet (milk vs. electrolytes) and type of vehicle (conditioned truck vs. open truck) on the difference between pretransport (collection center, CC) and posttransport ( $0 \mathrm{~h}, \mathrm{~T} 0)$ measurements (deltas, $\Delta=\mathrm{T} 0-\mathrm{CC}$ ) in young veal calves

\begin{tabular}{lcccccccc}
\hline & \multicolumn{2}{c}{ Milk } & & \multicolumn{2}{c}{ Electrolytes } & & \\
\cline { 2 - 3 } Parameter & Conditioned & Open & & Conditioned & Open & SEM $^{1}$ & $\begin{array}{c}P \text {-value } \\
\text { interaction }\end{array}$ \\
\hline Lactate, $\mathrm{mmol} / \mathrm{L}$ & $0.10^{\mathrm{a}}$ & $-0.41^{\mathrm{b}}$ & & $0.14^{\mathrm{a}}$ & $0.19^{\mathrm{a}}$ & 0.11 & 0.01 \\
Albumin, $\mathrm{g} / \mathrm{L}$ & $-2.27^{\mathrm{ab}}$ & $-3.43^{\mathrm{a}}$ & & $-2.50^{\mathrm{a}}$ & $-0.40^{\mathrm{b}}$ & & 0.72 & 0.03 \\
\hline
\end{tabular}

a,b Least squares means within a row lacking a common superscript differ $(P<0.05)$.

${ }^{1} \mathrm{SEM}=$ pooled standard error.

Blood NEFA concentrations increased in both milk-fed and electrolyte-fed calves after $18 \mathrm{~h}$ of transport. In contrast, after $6 \mathrm{~h}$ of transport, milk-fed calves decreased their NEFA concentration, whereas electrolyte-fed calves increased their NEFA concentration $(P=0.007)$. Moreover, milk-fed calves transported for $6 \mathrm{~h}$ increased glucose and decreased NEFA concentrations during transport compared with milk-fed calves transported for $18 \mathrm{~h}$. Milk-fed and electrolyte-fed calves did not differ in their change in blood TP concentrations after 18 $\mathrm{h}$ of transport, but after $6 \mathrm{~h}$ of transport, TP concentrations increased in milk-fed calves and decreased in electrolyte-fed calves $(P=0.002)$. In addition, milk-fed calves transported for $6 \mathrm{~h}$ increased TP concentrations during transport, whereas the ones transported for 18 $h$ had decreasing TP concentrations.

An interaction between pretransport diet and duration was also detected for BW losses (Table 3). Body weight losses were pronounced in both milk-fed or electrolyte-fed calves after $18 \mathrm{~h}$ of transport, but calves transported for $6 \mathrm{~h}$ and fed with milk increased in BW, whereas electrolyte-fed calves showed BW losses $(P=$ $0.03)$.

\section{Interaction Between Pretransport Diet and Type of Vehicle: Effects on the Difference Between Pre- and Posttransport Measurements}

No interactions between pretransport diet (milk or electrolytes) and type of vehicle (open or conditioned truck) were found for any of the variables determined immediately posttransport (T0).

An interaction between pretransport diet and type of vehicle was detected for deltas of lactate and albumin (Table 4). Milk-fed and electrolyte-fed calves transported in the conditioned truck increased to the same degree in lactate concentration during transport. However, in the open truck, milk-fed calves decreased lactate concentrations, whereas electrolyte-fed calves increased their lactate concentration $(P=0.01)$.

Albumin concentrations decreased in both milk-fed and electrolyte-fed calves transported in both type of vehicles. The decrease in albumin concentration did not differ between milk-fed or electrolyte-fed calves transported in the conditioned truck. However, milk-fed calves had a greater decline in albumin than electrolytefed calves in the open truck $(P=0.03)$.

\section{Main Effects of Pretransport Diet, Type of Vehicle, and Transport Duration}

Effects on Measurements Immediately Posttransport. Immediately posttransport, milk-fed calves had lower BHB levels than electrolyte-fed calves $(\Delta$ $=-0.213 \mathrm{mmol} / \mathrm{L} ; P<0.001$; Table 5). Pretransport diet, type of vehicle, and transport duration had no significant effects on BW and RT immediately posttransport.

Effects on the Difference Between Pre- and Posttransport Measurements. Pretransport diet influenced deltas of blood urea, BHB, and CK between pre- and posttransport (Table 6). Both milk-fed and electrolyte-fed calves increased urea $(P=0.03)$, BHB $(P<0.01)$, and CK $(P<0.01)$ during transport. However, the increase was greater in electrolyte-fed calves than in milk-fed calves.

Pretransport diet had also an effect on MCV, MCHC, calcium, and magnesium values. The MCV decreased in both milk-fed and electrolyte-fed calves during transport, but the decrease was larger in the milk-fed calves $(P=0.04)$ than in the electrolyte-fed calves. The MCHC, calcium, and magnesium values increased in milk-fed calves during transport, whereas the values decreased in electrolyte-fed calves. In addition, milk-fed calves had a greater increase in RT than electrolyte-fed calves during transport $(P<0.01)$.

Type of vehicle influenced MCHC values, osmolality, $\mathrm{CK}$, and sodium concentration and change in RT. The MCHC values increased in calves transported in the open truck and decreased in calves in the conditioned truck $(P=0.04)$. Calves in the open truck showed a decrease in osmolality and sodium values during transport, whereas calves in the conditioned truck increased these values $(P<0.05)$. Values of $\mathrm{CK}$ and RT increased 


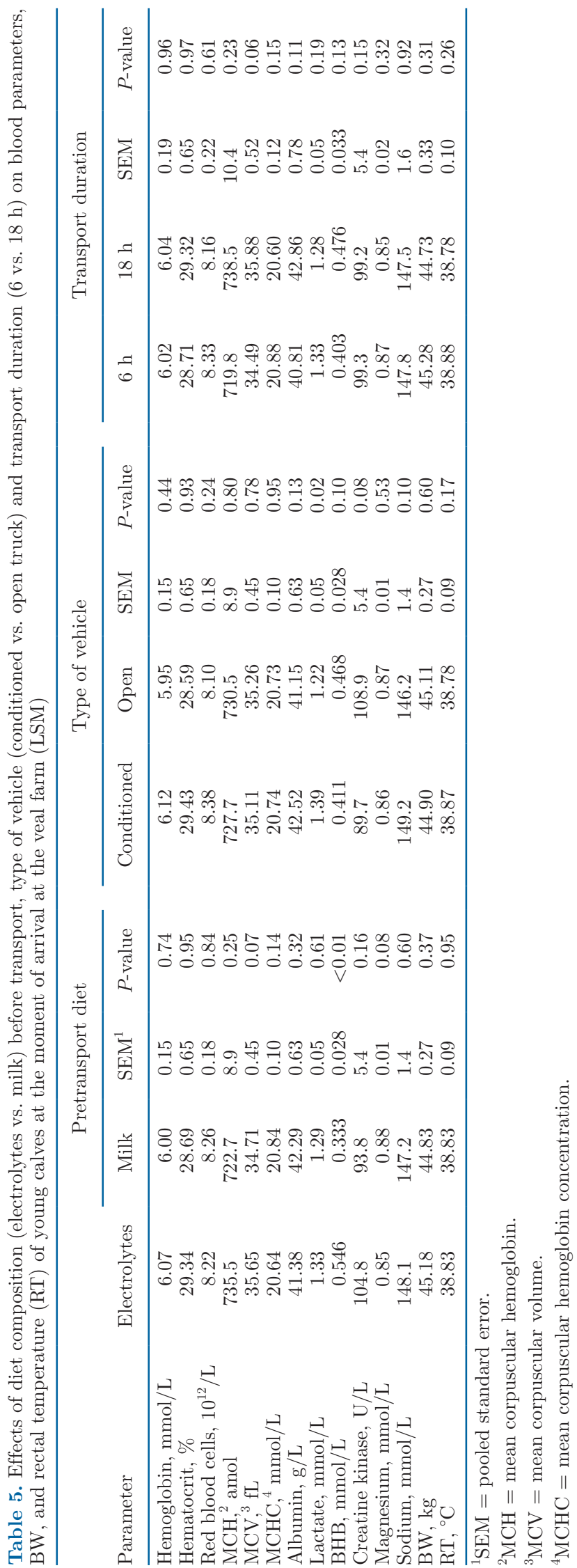

during transport in calves in both the open and the conditioned truck, but the increase in CK was higher in the open truck, whereas the increase in RT was higher in the conditioned truck (both $P<0.05$ ).

Transport duration had an effect on $\mathrm{MHCH}, \mathrm{BHB}$, calcium, and magnesium. After $6 \mathrm{~h}$ of transport, $\mathrm{MCHC}$ increased to a greater extent than after $18 \mathrm{~h}(P=0.01)$. In case of $\mathrm{BHB}$, higher concentrations were found in calves transported for $18 \mathrm{~h}$ than for $6 \mathrm{~h}(P=0.02)$. Both calcium and magnesium concentrations decreased in calves transported for $18 \mathrm{~h}$, whereas concentrations increased in calves transported for $6 \mathrm{~h}(P<0.05)$.

\section{Effects of Treatments in Time Until Wk 5 Posttransport}

Interaction Between Pretransport Diet and Time. Glucose, CK, NEFA, and BHB showed a significant interaction between pretransport diet and time (Figure 1A-D). Directly posttransport, milk-fed calves had higher glucose concentrations than electrolyte-fed calves (Figure 1A; $P=0.004$ ). However, $4 \mathrm{~h}$ posttransport, milk-fed calves had a lower concentration of glucose than the electrolyte-fed calves $(P=0.003)$. The amount of CK differed at T24 $(P=0.01)$, with milkfed calves showing lower CK values than electrolyte-fed calves (Figure 1B). The increase in NEFA and BHB directly posttransport was greater in electrolyte-fed calves than in milk-fed calves (Figure 1C, D; $P<$ 0.0001). At T4, concentrations of BHB were still higher in electrolyte-fed calves than milk-fed calves $(P=$ $0.0002)$.

Interaction Between Transport Duration and Time. An interaction between transport duration and time was found for most of blood metabolites (Figure 2A-H). As depicted in Figure 2A, at T0, calves transported for $18 \mathrm{~h}$ had lower glucose concentration than calves transported for $6 \mathrm{~h}(P<0.0001)$. At T24, glucose was also higher in calves transported for $6 \mathrm{~h}$ than in calves transported for $18 \mathrm{~h}(P=0.007)$. Blood urea, $\mathrm{BHB}$, and NEFA increased posttransport and then they decreased until wk 5 (Figure 2B-D). However, the response of calves was different between 6 and $18 \mathrm{~h}$ of transport. Calves transported for $18 \mathrm{~h}$ presented slightly higher urea concentrations from T0 until T24 than calves transported for $6 \mathrm{~h}(P<0.05)$. At T0 only, BHB and NEFA concentrations were also higher for calves transported for $18 \mathrm{~h}$ than the ones transported for $6 \mathrm{~h}$ $(P<0.01)$. Lactate, TP, and albumin concentrations differed at T48 (Figure $2 \mathrm{E}-\mathrm{G}$ ) between transport durations. At this sampling moment, calves transported for $6 \mathrm{~h}$ had higher lactate $(P<0.0001)$ and TP $(P=0.03)$ than calves transported for $18 \mathrm{~h}$, whereas the opposite was found for albumin concentration $(P=0.001)$. 

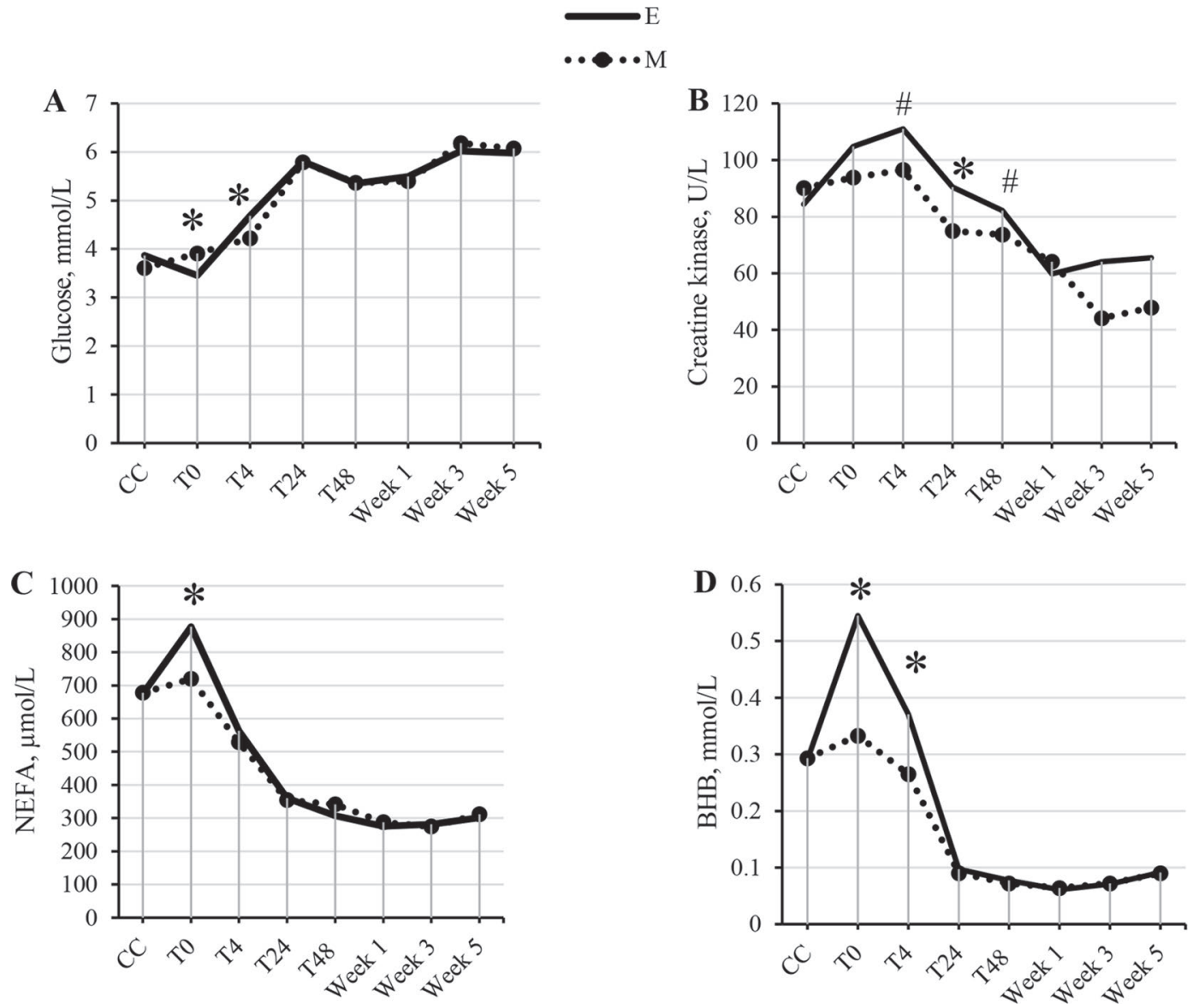

Figure 1. Interactions between pretransport diet [milk (M) vs. electrolytes (E)] and time relative to transport for glucose (A), creatine kinase (B), nonesterified fatty acids (NEFA; C), and BHB (D) in young veal calves. Blood samples of these variables were collected before transport at the collection center (CC); at 0 (T0), 4 (T4), 24 (T24), and 48 (T48) h; and 1, 3, and 5 wk posttransport. Asterisks indicate significant differences $(P \leq 0.05)$ between treatments within a sampling moment, whereas hashtags indicate a tendency toward significance $(0.05 \leq P \leq 0.10)$.

Osmolality decreased until T4 for calves transported either 6 or $18 \mathrm{~h}$ and thereafter started to rise; at T24, calves assigned to $18 \mathrm{~h}$ of transport showed a higher osmolality than calves assigned to $6 \mathrm{~h}$ of transport (Figure 2H; $P=0.0008$ ).

A significant interaction between transport duration and time was found for sodium, magnesium, and calcium (Figure 2J-L). Sodium showed the same trend in time as osmolality. Magnesium concentrations fluctuated within a small range. Compared with pretransport magnesium values, calves transported for $6 \mathrm{~h}$ had a small decrease in magnesium posttransport. After T0, magnesium concentrations fluctuated, with peak concentrations at T48 and wk 3 posttransport. Calves transported for $18 \mathrm{~h}$ had increasing concentrations of magnesium from T0 until wk 3 . Immediately posttransport and at T4, calves with $6 \mathrm{~h}$ of transport had higher calcium values than calves with $18 \mathrm{~h}$ of transport $(P=$ 0.002). In contrast, at T48, calves with $18 \mathrm{~h}$ of trans- port showed greater calcium concentrations than calves with $6 \mathrm{~h}$ of transport $(P=0.003)$.

\section{DISCUSSION}

In the current study, transport was a challenge for young veal calves. This is in line with previous studies that showed effects of transport on calf metabolic and physiological status (Knowles et al., 1999; Minka and Ayo, 2010). This study aimed to investigate effects of transport on young calves whose blood values were already challenged before transport due to previous mixing, handling procedures, and transport to the CC, moving away from baseline values. Values of blood parameters are shown in Table 2 and were compared with reference values for calves of $14 \mathrm{~d}$ of age found in other studies. Values recorded at the CC were comparable among treatment groups. Additionally, for many parameters recorded in the current experiment, especially 

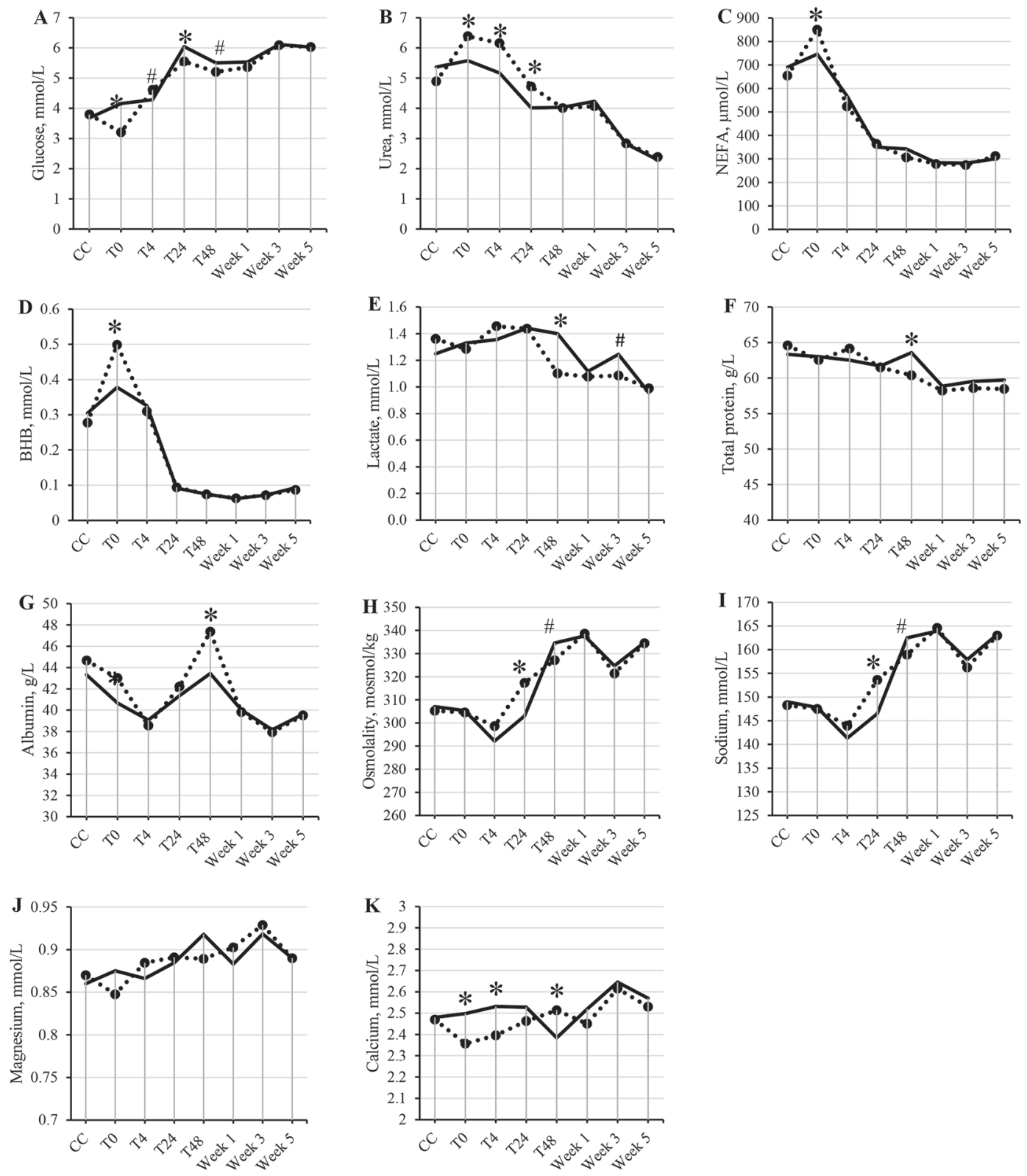

Figure 2. Interactions between transport duration (6 vs. $18 \mathrm{~h}$ ) and time relative to transport for glucose (A), urea (B), nonesterified fatty acids (NEFA; C), BHB (D), lactate (E), total protein (F), albumin $(\mathrm{G})$, osmolality $(\mathrm{H})$, sodium (I), magnesium (J), and calcium (K) in young veal calves. Blood samples of these variables were collected before transport at the collection center (CC); at 0 (T0), 4 (T4), 24 (T24), and 48 (T48) h; and 1,3, and 5 wk posttransport. Asterisks indicate significant differences $(P \leq 0.05)$ between treatments within a sampling moment, whereas hashtags indicate a tendency toward significance $(0.05 \leq P \leq 0.10)$.

those related to minerals, fat mobilization, such as NEFA, and energy, such as glucose, the values obtained at the $\mathrm{CC}$ were already markedly different from reference values. This strongly suggests that calves used in the current experiment were already challenged when the first blood sample was taken. Indeed, we deliberately used calves in our study as they commonly exist in practice (i.e., animals collected from different dairy farms in Germany, received and mixed at a CC, and then transported toward a veal farm in the Netherlands). Therefore, before arrival at the CC they most likely already had experienced different sorts of stressors, such as handling procedures and transport, as well as different durations of feed and water withdrawal. 


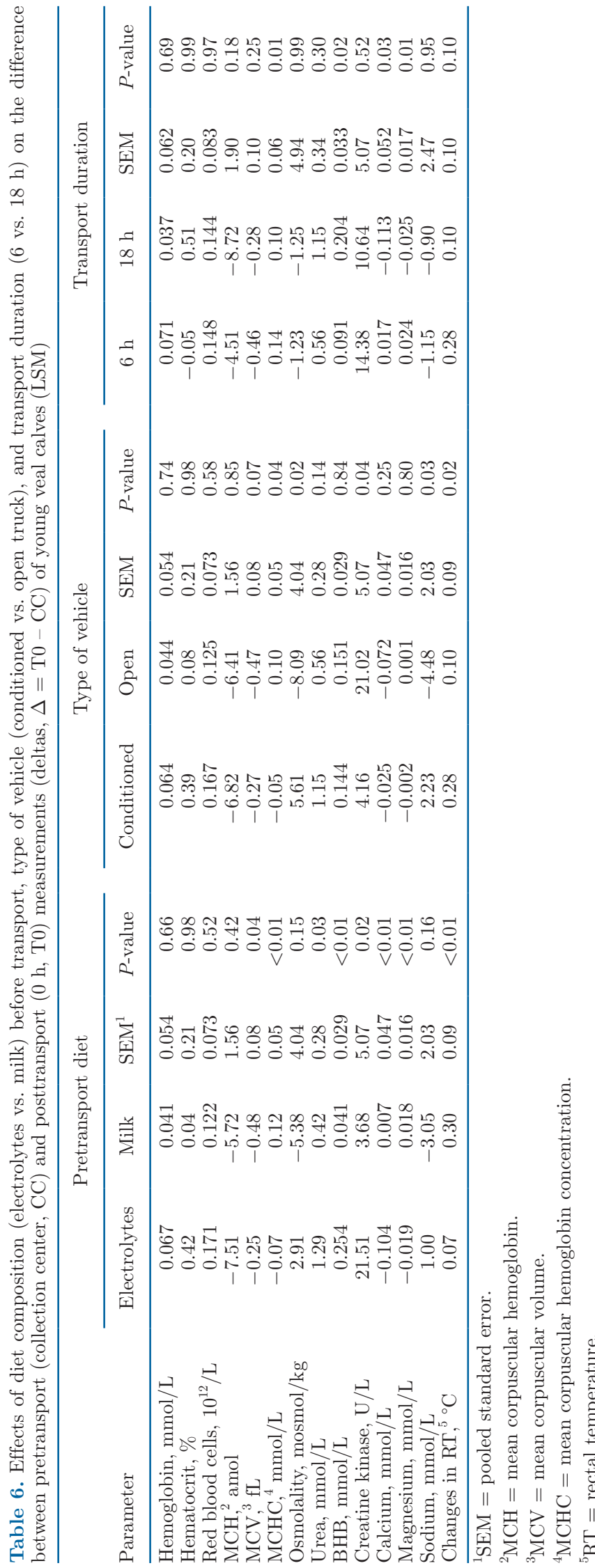

\section{Interaction Between Pretransport Diet and Transport Duration}

Milk-fed calves had higher TP and osmolality after $6 \mathrm{~h}$ of transport compared with electrolyte-fed calves. However, after $18 \mathrm{~h}$ of transport the effect was reversed, and milk-fed calves had lower TP and osmolality. The differences between the short and the long-term transport might be explained by different effects of dietary energy content on plasma volume (Bachmann et al., 2012). Electrolytes might have provided an immediate rate of hydration due to their quicker absorption rate in the gut of calves compared with milk (Nouri and Constable, 2006; Constable et al., 2009). We hypothesized that the initial rate of hydration might not have been maintained until the end of $18 \mathrm{~h}$ of transport. In contrast, the higher energy content of milk might have contributed to a slower rate of plasma expansion (Bachmann et al., 2012), which might explain the lower dehydration level of the milk-fed calves after $18 \mathrm{~h}$ of transport compared with the electrolyte-fed calves.

After $18 \mathrm{~h}$ of transport, electrolyte-fed calves had higher calcium concentrations than milk-fed calves. The combination of lower energy content and long transport duration might explain the rise in calcium concentrations in electrolyte-fed calves in the present study. Parker et al. (2003) showed higher calcium concentrations in steers after $48 \mathrm{~h}$ of transport duration; however, the authors used older animals instead of young calves. Other studies did not show any significant results on calcium, thus more research is needed to investigate how calcium is regulated during long-term transport in young calves.

An interaction between pretransport diet and transport duration was also identified for BW losses and deltas between pretransport and immediate posttransport glucose and NEFA concentrations. After $18 \mathrm{~h}$ of transport, milk-fed and electrolyte-fed calves experienced BW losses. In accordance to previous studies on long transport duration, BW losses can be highly influenced by feeding and water provision before transport (Tarrant et al., 1992; Knowles et al., 1999). Bernardini et al. (2012) showed that after $19 \mathrm{~h}$ of transport calves had $6.4 \%$ higher BW losses compared with nontransported calves. Moreover, unfed calves or calves provided with only water and no food during transport are more prone to BW losses. In the study of Knowles et al. (1997), unfed calves that were transported for $24 \mathrm{~h}$ lost up to $3.2 \%$ of their BW. Although diet seemed to have no effects after $18 \mathrm{~h}$ of transport, the feeding strategy at the CC played an important role on BW losses after short transport duration. In the current practice, feeding electrolyte solutions before transport is a common approach to counteract expected negative effects of 
transport on electrolyte metabolism, metabolic acidosis, and viral diarrhea in cattle (Booth and Naylor, 1987; Schaefer et al., 1997). Knowles et al. (1997) used a glucose/electrolyte solution to avoid gastrointestinal problems on arrival at the farm. Despite the important role of electrolytes on calf health, the results of the present study showed that, after $6 \mathrm{~h}$ of transport, milkfed calves gained weight compared with electrolyte-fed calves that lost weight, although they had the same amount of fluid intake. This result suggests that the higher nutrient and energy content of milk seemed to protect calves against the effects of transport on nutrient mobilization and thus on BW losses.

The effect of feeding milk before $6 \mathrm{~h}$ of transport was also evident on blood biochemical profile. The higher glucose and lower NEFA concentrations in milk-fed calves posttransport are indicative of a less negative energy balance and might indicate that the nutrient reserve depletion is less serious than in electrolyte-fed calves (Tadich et al., 2005; Marcato et al., 2018). Moreover, the consequences of feeding electrolytes on calf energy and protein metabolism were more pronounced after long distance transport. This is in line with the study of Mormede et al. (1982) who found slightly lower posttransport glucose $(-38 \%$ for short transport and $-54 \%$ for long transport), and higher NEFA and urea levels. Mormede et al. (1982) suggested that the results might be due to the combination of food deprivation and the higher energy demands of transport and manipulations. On long journeys, food reserves are used by animals, thus a lower plasma glucose might be an indicator that the animal runs out of fast available energy (Grandin, 2014).

\section{Effects of Pretransport Diet}

Feeding electrolytes as pretransport diet contributed to a significant increase in CK during transport. Higher CK and lactate values might be indicative of calf tissue damage, hypoxia, fatigue, and exhaustion during transport (Chacon et al., 2005, Averos et al., 2008). In our study, the changes observed after short-term transport in milk-fed calves might be associated with the greater energy content of this diet that protects calves from glycogenolysis and gluconeogenesis induced by fear responses during transport.

Diet also influenced RBC parameters. The MCV and $\mathrm{MCHC}$ levels depend on $\mathrm{Hb}$ concentration. Changes in these blood parameters have been previously described in veal calves (Wilson et al., 2000) in relationship to a low iron dietary regimen at the veal farm, but whether other (transport-related) factors also might play a role is currently not clear.
The higher RT in milk-fed calves might be explained by the higher energy content of their diet compared with electrolytes, and consequently a higher metabolic rate (Scibilia et al., 1987).

In our study, milk-fed calves had an increase in their calcium and magnesium concentration posttransport, whereas electrolyte-fed calves experienced a decrease. Calcium and magnesium are important macrominerals that have key functions in body signaling and enzymes. Magnesium is not stored in the body and needs to be ingested daily. Calcium is well regulated and can derive from bone via the parathyroid hormone. Their main role together with other ions, such as chloride and sodium, is the maintenance of acid-base balance, osmotic pressure, membrane electric potential, and nervous transmission (Mohri et al., 2008). Transportation is known to affect mineral balance in calves (Schaefer et al., 1997; Steinhardt and Hans-Herma, 1998). In the literature, an increase in calcium and magnesium values is generally associated with the activation of the hypothalamic-pituitary-adrenal axis during transport. As a result of high calcium in the extracellular fluids, challenged animals have greater muscle contractility (Minka and Ayo, 2010). In this experiment, the difference in concentrations of these minerals between milkfed and electrolyte-fed calves might be a consequence of diet instead of the activation of the hypothalamic-pituitary-adrenal axis during transport. Milk contained 9.5 $\mathrm{g} / \mathrm{kg}$ of calcium and $1.67 \mathrm{~g} / \mathrm{kg}$ of magnesium, whereas these minerals were not included in the nutrient composition of electrolytes. The greater nutrient content in milk might, therefore, have contributed to the increase in calcium and magnesium.

\section{Effects of Transport Duration}

Long transport duration affected differences in mineral concentrations between pre- and posttransport. Steinhardt and Hans-Herma (1998) found a decrease in calcium and magnesium concentrations after transport of calves. The decrease in these minerals was probably due to fear responses experienced by calves during transport and handling procedures. Lower calcium and magnesium, as well as fear responses, increase catecholamine production, and result in higher cell permeability (Davidson et al., 2004). Moreover, a reduction in magnesium concentrations leads to an increase in glycogen breakdown (Steinhardt and Hans-Herma, 1998). Thus, it is important to maintain mineral homeostasis to prevent any consequences on calf metabolism and physiology. In our study, a decrease in calcium and magnesium values was observed only after $18 \mathrm{~h}$ of transport and not after $6 \mathrm{~h}$ of transport. Therefore, long transport 
duration seemed to exert more negative effects on these minerals compared with short transport duration.

\section{Effects of the Type of Vehicle}

Apparently, and contrary to our expectations, in our study the settings of the climate control system as applied in practice did not result in notable differences in temperature or relative humidity between the conditioned and open truck. This might explain the fact that, in the current experiment, the type of vehicle had a small influence on posttransport metabolic parameters of calves. Nevertheless, the type of vehicle influenced deltas of osmolality, RT, and sodium between pre- and posttransport. Perhaps climatic parameters other than those recorded in the present experiment differed between the conditioned and open truck, such as draft, which may have affected the physiological state of our calves. Moreover, a different season (e.g., summer) might have caused more notable differences in physiological measurements; however, to our knowledge, no studies are available on the effects of season in association with different type of vehicle on physiology of young calves. From higher osmolality and sodium values, it can be speculated that calves in the conditioned truck experienced more dehydration, which might have compromised their thermoregulatory abilities, resulting in increased RT (Minka and Ayo, 2010). Follow-up studies are needed to much better and more comprehensively characterize climatic conditions in open and in conditioned vehicles during transport, and to examine which environmental factors inside the truck are (most) relevant for calf physiology and health. In addition, our study indicates that there is a need for the definition of scientifically based reference values of settings for climate control systems for livestock transport trucks, especially those for the transport of young calves.

\section{Interaction Between Pretransport Diet and Type of Vehicle}

An interaction between pretransport diet and type of vehicle was detected for albumin. Albumin is a protein synthesized in the liver (Klinkon and Ježek, 2012), is responsible for $75 \%$ of the osmotic pressure of plasma, and is considered a major negative acute phase protein (Tothova et al., 2014). Therefore, a decrease in albumin could be associated with an ongoing inflammatory process (Petersen et al., 2004). In our study, electrolyte-fed calves exhibited a smaller decrease in albumin during transport than milk-fed ones, but only in the open truck (Table 4). However, we have no indication that these specific treatment groups also demonstrated signs of inflammation. Hence, the reasons behind this particular finding remain to be determined.

\section{Effects of Experimental Treatments on Variables Until Wk 5 Posttransport}

In our experiment, an interaction between pretransport diet and time was present for both glucose and NEFA. Around T0, milk-fed calves had higher glucose and slightly lower NEFA in the blood. The feed-related differences in glucose and NEFA remained evident until $4 \mathrm{~h}$ posttransport. This is in line with the study of Knowles et al. (1999). The authors reported that glucose and NEFA concentrations of calves returned to pretransport values within $4 \mathrm{~h}$ of the end of transport. Therefore, the effect of pretransport diet on these blood measurements was visible only for a short term posttransport.

An interaction between transport duration and time was detected for energy and protein indicators, dehydration indicators, and minerals. Effects of transport duration on glucose, BHB, and NEFA concentrations were detected in the first $4 \mathrm{~h}$ posttransport. Around T0, calves transported for $6 \mathrm{~h}$ had higher glucose and lower BHB and NEFA in their blood. After T4, the concentrations of these variables were similar for calves transported for 6 or $18 \mathrm{~h}$. The fast recovery time from energy depletion is also observed in the literature (Knowles et al., 1999). However, calves assigned to long transport duration maintained higher plasma urea concentrations until $48 \mathrm{~h}$ posttransport. These results might be also associated with fasting during a long journey to the veal farm. Immediately posttransport, Knowles et al. (1997) found higher urea concentrations (5.61 mmol/L) in unfed calves compared with calves being fed $(5.34 \mathrm{mmol} / \mathrm{L})$ during a 24 -h journey. Urea concentrations in unfed calves also increased up to $72 \mathrm{~h}$ posttransport (Knowles et al., 1997). Thus, results suggest that providing feed to calves before long transport might prevent muscle protein degradation in the first 2 $\mathrm{d}$ at the veal farm.

The significant increase in albumin, TP (only for $6 \mathrm{~h}$ of transport), and osmolality found $48 \mathrm{~h}$ posttransport might be related to the feeding management of calves at the veal farm. The calves in the current study ingested $1.5 \mathrm{~L}$ of milk or electrolytes at the $\mathrm{CC}$ and then were transported for up to $18 \mathrm{~h}$. At the veal farm, calves received $3 \mathrm{~L}$ of water with electrolytes immediately posttransport and only the next day did calves receive milk. This means that calves received only $4.5 \mathrm{~L}$ of fluid within $48 \mathrm{~h}$. Thus, the difference in management between the dairy farm and the veal farm might have resulted in a peak of dehydration $2 \mathrm{~d}$ posttransport. The effect was more pronounced in calves transported 
for $18 \mathrm{~h}$ due to their longer fasting period (Knowles et al., 1997). Compared with calves transported for $6 \mathrm{~h}$, calves transported for $18 \mathrm{~h}$ had lower TP concentrations $48 \mathrm{~h}$ posttransport. The lower TP concentration might be also associated with the decrease in other proteins (e.g., globulins). A lower $\alpha$-globulin accompanied by high albumin concentrations in calves transported for $18 \mathrm{~h}$ might be related to water loss (Alam et al., 2012), suggesting that these calves might have experienced dehydration at this time point. A great increase in sodium concentrations was particularly visible from $4 \mathrm{~h}(141.3$ $\mathrm{mmol} / \mathrm{L})$ to $48 \mathrm{~h}(162.5 \mathrm{mmol} / \mathrm{L})$ posttransport. The same trend was also seen in osmolality and it might suggest that the animals were dehydrated between 4 and $48 \mathrm{~h}$ posttransport.

Based on glucose and NEFA concentrations, it can be concluded that recovery rate of calves posttransport is quick because concentrations were returning to (below) pretransport values in a short term posttransport. However, effects of transport duration on urea and dehydration indicators were still evident until $48 \mathrm{~h}$ posttransport, and thus for a longer term, which might be related to differences in feeding strategies between dairy farms and veal farms.

\section{CONCLUSIONS}

In this study, pretransport diet provided at the collection center and transport duration had a significant effect on the hematological profile and physiological status of young veal calves. Feeding milk before transport and short transport duration reduced utilization of glucose as a primary source of energy and prevented mobilization of fat and protein, and BW losses. However, calves transported for $18 \mathrm{~h}$ were more dehydrated, as suggested by increasing concentrations of albumin and osmolality at $48 \mathrm{~h}$ posttransport and feeding milk before transport was not able to prevent these increases in blood values. The recovery rate of calves posttransport was quick since calves restored their (below) pretransport values within $24 \mathrm{~h}$ posttransport. Type of vehicle had little influence on calf metabolic parameters. The potential implications of differences in hematological profile and physiological status of calves upon arrival at the veal farm for later clinical health and disease incidence during the rearing period remains to be determined and will be the subject of follow-up research.

\section{ACKNOWLEDGMENTS}

The authors gratefully acknowledge representatives of the Dutch veal and livestock transport industries for providing personal support and facilities, and Rimondia B.V. (Elspeet, the Netherlands) for help dur- ing blood sampling and analyses. We want to thank Rudie Koopmanschap and Ger de Vries-Reiligh, Henk Gunnink, Theo van Hattum, Henny Reimert, Joop van der Werf, Bjorge Lauressen, Monique Ooms, Ilona van den Anker, Manon van Marwijk, Joop Aarts, Eline Burgers, Lu Luo, Wei Xu, Deborah Vexelman, Suze Moms, and Lotte Hermeling (Wageningen University, Wageningen, the Netherlands) for their skilled technical and laboratory assistance during various parts of the experiment. This study was financially supported by Stichting Brancheorganisatie Kalversector (SBK, Nieuwegein, the Netherlands) and the Dutch Ministry of Agriculture, Nature and Food Quality (The Hague, the Netherlands). The authors have not stated any conflicts of interest.

\section{REFERENCES}

Alam, M. R., W. I. Kim, J. W. Kim, C. S. Na, and N. S. Kim. 2012. Effects of Chitosan-oligosaccharide on diarrhoea in Hanwoo calves. Veterinarni Medicina 1:57. https://doi.org/10.17221/6306 -VETMED.

Autio, T., T. Pohjanvirta, R. Holopainen, U. Rikula, J. Pentikainen, A. Huovilainen, H. Rusanen, T. Soveri, L. Sihvonen, and S. Pelkonen. 2007. Etiology of respiratory disease in non-vaccinated, non-medicated calves in rearing herds. Vet. Microbiol. 119:256265. https://doi.org/10.1016/j.vetmic.2006.10.001.

Averós, X., S. Martin, M. Riu, J. Serratosa, and L. F. Gosalvez. 2008. Stress response of extensively reared young bulls being transported to growing-finishing farms under Spanish summer commercial conditions. Livest. Sci. 119:174-182. https://doi.org/10.1016/j.livsci .2008.04.002.

Bachmann, L., B. Schmidt, U. Rauwolf, J. Wenge, and M. Coenen. 2012. Change of plasma volume, osmolality, and acid-base status in healthy calves after feeding of milk and water-and milk-based oral rehydration solutions. J. Dairy Sci. 95:6006-6014. https://doi .org/10.3168/jds.2012-5562.

Bernardini, D., G. Gerardi, A. Peli, L. Nanni Costa, M. Amadori, and S. Segato. 2012. The effects of different environmental conditions on thermoregulation and clinical and hematological variables in long-distance road-transported calves. J. Anim. Sci. 90:1183-1191. https://doi.org/10.2527/jas.2011-4113.

Booth, A. J., and J. Naylor. 1987. Correction of metabolic acidosis in diarrheal calves by oral administration of electrolyte solutions with or without bicarbonate. J. Am. Vet. Med. A 191:62-68.

Buckham Sporer, K. R., P. Weber, J. Burton, B. Earley, and M. Crowe. 2008. Transportation of young beef bulls alters circulating physiological parameters that may be effective biomarkers of stress. J. Anim. Sci. 86:1325-1334. https://doi.org/10.2527/jas.2007-0762.

Buczinski, S., M. Borris, and J. Dubuc. 2018. Herd-level prevalence of the ultrasonographic lung lesions associated with bovine respiratory disease and related environmental risk factors. J. Dairy Sci 101:2423-2432. https://doi.org/10.3168/jds.2017-13459.

Chacon, G., S. Garcia-Belenguer, M. Villarroel, and G. A. Maria 2005. Effect of transport stress on physiological responses of male bovines. DTW Deutsche Tierarztliche Wochenschrift 112:465-469.

Constable, P., W. Grünberg, and L. Carstensen. 2009. Comparative effects of two oral rehydration solutions on milk clotting, abomasal luminal $\mathrm{pH}$, and abomasal emptying rate in suckling calves. J. Dairy Sci. 92:296-312. https://doi.org/10.3168/jds.2008-1462.

Constable, P., P. Walker, D. Morin, and J. Foreman. 1998. Clinical and laboratory assessment of hydration status of neonatal calves with diarrhea. J. Am. Vet. Med. Assoc. 212:991-996.

Davidson, A., R. McConnico, M. Mitchell, J. Hubert, and L. CoatesMarkle. 2004. The effect of pre-treatment with oral electrolytes on 
serum cortisol and other haematological parameters in a group of feral horses transported by road. Vet. J. 168:199.

Earley, B., K. B. Sporer, and S. Gupta. 2017. Invited review: Relationship between cattle transport, immunity and respiratory disease. Animal 11:486-492. https://doi.org/10.1017/S1751731116001622.

Gebresenbet, G., I. Wikner, E. Y. H. Bobobee, G. Maria, and M. Villarroel. 2012. Effect of transport time and handling on physiological responses of cattle. J. Agric. Sci. Technol. A 2:800

Grandin, T. 2014. Livestock Handling and Transport. 4th ed. CABI, Boston, MA

Grigor, P. N., M. S. Cockram, W. B. Steele, C. J. Le Sueur, R. E. Forsyth, J. A. Guthrie, A. K. Johnson, V. Sandilands, H. W. Reid, C. Sinclair, and H. K. Brown. 2001. Effects of space allowance during transport and duration of mid-journey lairage period on the physiological, behavioural and immunological responses of young calves during and after transport. Anim. Sci. 73:341-360. https:// doi.org/10.1017/S135772980005832X.

Hulbert, L. E., and S. J. Moisa. 2016. Stress, immunity, and the management of calves. J. Dairy Sci. 99:3199-3216. https://doi.org/10 $.3168 /$ jds.2015-10198.

Kenward, M. G., and J. H. Roger. 1997. Small sample inference for fixed effects from restricted maximum likelihood. Biometrics 53:983-997. https://doi.org/10.2307/2533558.

Klinkon, M., and J. Ježek. 2012. Values of blood variables in calves. Pages 301-320 in A Bird's-Eye View of Veterinary Medicine. C. C. Perez-Marin, ed. InTech, Rijeka, Croatia.

Knowles, T. G., J. Edwards, K. Bazeley, S. Brown, A. Butterworth, and P. Warriss. 2000. Changes in the blood biochemical and haematological profile of neonatal calves with age. Vet. Rec. 147:593598. https://doi.org/10.1136/vr.147.21.593

Knowles, T., P. Warriss, S. Brown, J. Edwards, P. Watkins, and A Phillips. 1997. Effects on calves less than one month old of feeding or not feeding them during road transport of up to 24 hours. Vet. Rec. 140:116-124. https://doi.org/10.1136/vr.140.5.116.

Knowles, T. G., S. N. Brown, J. E. Edwards, A. J. Phillips, and P. D. Warriss. 1999. Effect on young calves of a one-hour feeding stop during a 19-hour road journey. Vet. Rec. 144:687-692. https://doi .org/10.1136/vr.144.25.687.

Marcato, F., H. van den Brand, B. Kemp, and K. van Reenen. 2018. Evaluating potential biomarkers of health and performance in veal calves. Front. Vet. Sci. 5:133. https://doi.org/10.3389/fvets.2018 .00133

Minka, N. S., and J. O. Ayo. 2010. Physiological responses of food animals to road transportation stress. Afr. J. Biotechnol. 9:6601-6613.

Mohri, M., H. A. Seifi, and F. Daraei. 2008. Effects of short-term supplementation of clinoptilolite in colostrum and milk on hematology, serum proteins, performance, and health in neonatal dairy calves. Food Chem. Toxicol. 46:2112-2117. https://doi.org/10 $.1016 /$ j.fct.2008.02.003.

Mohri, M., K. Sharifi, and S. Eidi. 2007. Hematology and serum biochemistry of Holstein dairy calves: Age related changes and comparison with blood composition in adults. Res. Vet. Sci. 83:30-39. https://doi.org/10.1016/j.rvsc.2006.10.017.

Mormede, P., J. Soissons, R. M. Bluthe, J. Raoult, G. Legarff, D. Levieux, and R. Dantzer. 1982. Effect of transportation on blood serum composition, disease incidence, and production traits in young calves. Influence of the journey duration. Ann. Rech. Vet. 13:369-384. https://hal.archives-ouvertes.fr/hal-00901393.

Nouri, M., and P. D. Constable. 2006. Comparison of two oral electrolyte solutions and route of administration on the abomasal emptying rate of Holstein-Friesian calves. J. Vet. Intern. Med. 20:620 626. https://doi.org/10.1111/j.1939-1676.2006.tb02906.x.

Pardon, B., J. Alliet, R. Boone, S. Roelandt, B. Valgaeren, and P. Deprez. 2015. Prediction of respiratory disease and diarrhea in veal calves based on immunoglobulin levels and the serostatus for respiratory pathogens measured at arrival. Prev. Vet. Med. 120:169-176. https://doi.org/10.1016/j.prevetmed.2015.04.009.
Pardon, B., M. Hostens, L. Duchateau, J. Dewulf, K. De Bleecker, and P. Deprez. 2013. Impact of respiratory disease, diarrhea, otitis and arthritis on mortality and carcass traits in white veal calves. BMC Vet. Res. 9:79. https://doi.org/10.1186/1746-6148-9-79.

Parker, A. J., G. P. Hamlin, C. J. Coleman, and L. A. Fitzpatrick. 2003. Quantitative analysis of acid-base balance in Bos indicus steers subjected to transportation of long duration. J. Anim. Sci. 81:1434-1439. https://doi.org/10.2527/2003.8161434x.

Petersen, H. H., J. P. Nielsen, and P. M. Heegaard. 2004. Application of acute phase protein measurements in veterinary clinical chemistry. Vet. Res. 35:163-187. https://doi.org/10.1051/vetres:2004002.

Renaud, D. L., T. Duffield, S. LeBlanc, D. Haley, and D. Kelton. 2018. Clinical and metabolic indicators associated with early mortality at a milk-fed veal facility: A prospective case-control study. J. Dairy Sci. 101:2669-2678. https://doi.org/10.3168/jds.2017-14042.

SBK. 2018. Protocol Gezonde Kalveren - Vitaal Kalf. Accessed Oct. 3, 2019. https://www.kalversector.nl/wp-content/uploads/2018/ 03/SBK-KVK-BIJL-700-02-20180401-Protocol-Gezonde-Kalveren .pdf (in Dutch).

Schaefer, A. L., S. D. M. Jones, and R. W. Stanley. 1997. The use of electrolyte solutions for the reducing transport stress. J. Anim. Sci. 75:258-265. https://doi.org/10.2527/1997.751258x.

Schrama, J. W., A. Arieli, H. Brandsma, P. Luiting, and M. Verstegen. 1993. Thermal requirements of young calves during standing and lying. J. Anim. Sci. 71:3285-3292. https://doi.org/10.2527/1993 $.71123285 x$.

Schwartzkopf-Genswein, K. S., M. E. Booth-McLean, M. A. Shah, T. Entz, S. J. Bach, G. J. Mears, A. L. Schaefer, N. Cook, J. Church and T. A. McAllister. 2007. Effects of pre-haul management and transport duration on beef calf performance and welfare. Appl. Anim. Behav. Sci. 108:12-30. https://doi.org/10.1016/j.applanim 2006.11.012.

Scibilia, L. S., L. Muller, R. Kensinger, T. Sweeney, and P. Shellenberger. 1987. Effect of environmental temperature and dietary fat on growth and physiological responses of newborn calves. J. Dairy Sci. 70:1426-1433. https://doi.org/10.3168/jds.S0022 -0302(87)80165-0.

Steinhardt, M., and T. Hans-Herma. 1998. Development of calves during the milk feed period and forms of reaction of these animals to transport by road. Anim. Res. Dev. 47:85-101.

Tadich, N., C. Gallo, H. Bustamante, M. Schwerter, and G. van Schaik. 2005. Effects of transport and lairage time on some blood constituents of Friesian-cross steers in Chile. Livest. Prod. Sci. 93:223-233. https://doi.org/10.1016/j.livprodsci.2004.10.004

Tarrant, P. V., F. J. Kenny, D. Harrington, and M. Murphy. 1992. Long distance transportation of steers to slaughter: effect of stocking density on physiology, behavior and carcass quality. Livest. Prod. Sci. 30:223-238. https://doi.org/10.1016/S0301-6226(06)80012-6.

Tothova, C., O. Nagy, and G. Kovac. 2014. Acute phase proteins and their use in the diagnosis of diseases in ruminants: A review. Vet. Med. (Praha) 59:163-180. https://doi.org/10.17221/7478 -VETMED.

Wilson, L. L., J. Smith, D. Smith, D. Swanson, T. Drake, D. Wolfgang, and E. Wheeler. 2000. Characteristics of veal calves upon arrival, at 28 and 84 days, and at end of the production cycle. J. Dairy Sci. 83:843-854. https://doi.org/10.3168/jds.S0022-0302(00)74948-4.

\section{ORCIDS}

F. Marcato ๑ https://orcid.org/0000-0002-7063-5955

H. van den Brand () https://orcid.org/0000-0003-0477-169X

B. Engel ๑ https://orcid.org/0000-0002-7680-326X

M. Wolthuis-Fillerup @ () https://orcid.org/0000-0001-9226-0368 


\section{APPENDIX}

A)

B)
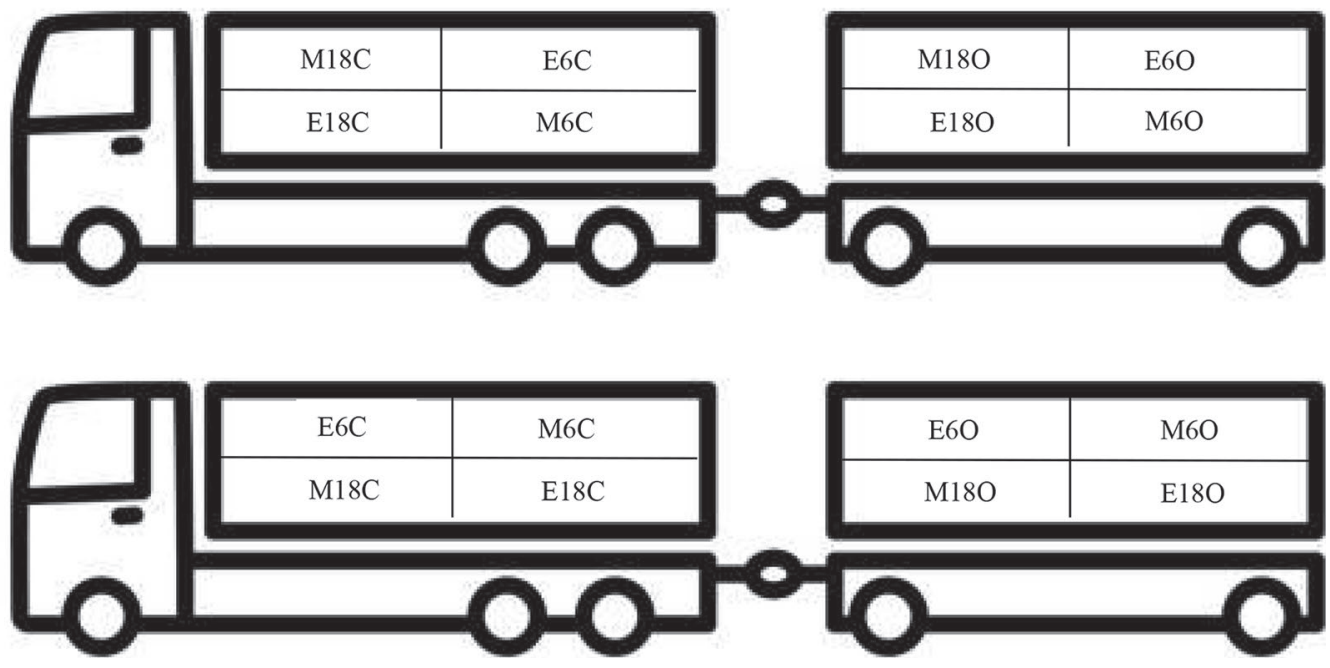

Figure A1. Design of the truck and the trailer for batch 1 (A) and batch 2 (B) of calves. M6C $=$ milk, $6 \mathrm{~h}$ of transport, conditioned truck; $\mathrm{M} 18 \mathrm{C}=$ milk, $18 \mathrm{~h}$ of transport, conditioned truck; $\mathrm{M} 6 \mathrm{O}=$ milk, $6 \mathrm{~h}$ of transport, open truck; $\mathrm{M} 18 \mathrm{O}=$ milk, $18 \mathrm{~h}$ of transport, open truck; $\mathrm{E} 6 \mathrm{C}=$ electrolytes, $6 \mathrm{~h}$ of transport, conditioned truck; E18C = electrolytes, $18 \mathrm{~h}$ of transport, conditioned truck; E6O = electrolytes, $6 \mathrm{~h}$ of transport, open truck; E18O = electrolytes, 18 h of transport, open truck. 